\title{
A HAZAI KŌRNYEZETVÉDELMI INFRASTRUKTÚRA FEJLESZTÉSI PROJEKTEK SZERVEZETI HÁTTERE
}

\author{
Szabó Ferenc \\ óraadó \\ Szegedi Tudományegyetem Mérnöki Kar
}

\begin{abstract}
SUMMARY
Effective planning, preparation, implementation and operation of projects need modern organisational solutions. Successful project management requires effective daily operation, flexible structure, adaptive and innovative organisational culture, coordination mechanisms that assure fast decision-making and responses. The appropriate organisational form is based on personal motivation and responsibility, parallel with the possibility of cooperation and teamwork.

Several international, national, regional and local organisations are involved in Hungarian environmental infrastructure development projects supported by the EU. Their organisational structures and cultures are not always optimal for project management. Organizational differences in some cases make effective cooperation impossible.

In my paper I present the organisational background of one of these projects, the Szeged Regional Waste Management Program based on intervicws conducted with some actors of the project, casc studies and document analysis.
\end{abstract}

\section{BEVEZETÉS}

A hazai környezetvédelmi infrastruktúra lemaradása a világ fejlettebb régióihoz képest még ma is számottevő. Az ország felzárkóztatása szempontjából az európai uniós csatlakozás rendkívüli lebetöségeket teremtett. Az európai források (ISPA program) a csatlakozási folyamat kezdetétöl rendelkezésre álltak, számos jelentős projekt előkészitése és bonyolítása kezdödött el négy évvel a tényleges csatlakozást megelözően, még 2000-ben. A 2004. május 1-jei csatlakozást követően az ISPA projektek, változatlan feltételek mellett Kohéziós Alap projektekké alakultak.

A projektek hatékony tervezése, elökészitése, megvalósitása és müködtetése korszerü szervezeti megoldásokat igényel. Hatékony napi müködés, rugalmas struktúra, adaptiv és 
innovatịv szervezeti kultúra, gyors döntéseket és reagálást biztositó koordinációs mechanizmusok, egyéni motiváción és felelősségvállaláson alapuló, ugyanakkor az együttmûködést és a csapatmunkát is lehetővé tevô szervezeti forma, stratégiai szemléleten és ésszerü kockázatvállaláson alapuló megkōzelítések alkalmazása szükségesek az eredményes projektmenedzsmenthez. [Görög 2001]

A projektek elökészitése és lebonyolitása során számos támogató és a kedvezményezett szervezeti egységének kell hatékonyan együttmüködnie ahhoz, hogy a sikeres befejezés elérhető közelségbe kerüljön. A következökben a „Szeged regionális hulladékgazdálkodási programja" elnevezésü ISPA/Kohéziós Alap projekt szervezeti kérdéseit szeretném áttekinteni, elsösorban terjedelmi okok miatt a teljesség igénye nélkül. Esetünkben két támogató, az Európai Unió és a Magyar Kormány áll szemben a kedivezményezett 33 önkormányzattal, melyek konzorciumának gesztora Szeged Megyei Jogú Város Önkormányzata.

Doktori kutatásaim keretében interjúkat készítettem az EU által támogatott hazai környezetvédelmi infrastruktúra fejlesztési projektek előkészítésében és lebonyolításában résztvevő menedzserekkel, szakértőkkel. A beszélgetések során egyebek között arra kerestem a választ, milyen szervezeti tényezök akadályozzák a leginkább a hatékonyabb projektvezetést, lassítják a projektek lebonyolítását.

A szegedi hulladékgazdálkodási projekt esetében az önkormányzat megbízásából részt vettem a projekt elökészítésében és végrehajtásában is, igy a megfigyelés módszerének alkalmazására, és esettanulmány készitésére is alkalmam nyiltt. Ehhez többek között áttekintettem a projekt elökészítése és bonyolítása során keletkezett szerzödéseket, terveket, egyéb dokumentumokat is (lásd: Felhasznált dokumentumok).

A továbbiakban a projektmenedzsment szervezeti hátterével kapcsolatos vizsgálataim eredményeit kívánom összegezni.

\section{A TÁMOGATÓK SZERVEZETI EGYSÉGEI}

\subsection{Az Európai Unió}

Az EU többek között a regionális támogatásokért is felelős szervezeti egysége a Regionális Igazgatóság (DG Regio). A csatlakozás előtt az EU Magyarországi Delegációja felügyelte, irányította és ellenőrizte a projektek eiőkészítését, jóváhagyását és bonyolítását. A csatlakozást követően a Delegáció megszünt, feladatait hazai szervezetek vették át. 


\subsection{Hazai állami szervezetek}

Az első kömyezetvédelmi projektek elökészítésének megkezdésekor, 1999-2000-ben a KvVM Nemzetközi Támogatások Önálló Osztálya fogta össze a hazai projekteket, koordinálta az együttmüködést a támogatók és a kedvezményezettek között. 2002-ben ez az osztály a KvVM Fejlesztési Igazgatóságaként önálló intézménnyé alakult, saját székházba költözött, infrastruktúráját, személyi állományát jelentősen megerôsítették, feladata a kömyezetvédelmi infrastruktúra fejlesztési projektek koordinálása, szakmai felügyelete és irányítása.

A Nemzeti Fejlesztési Ügynökség (NFÜ) a 2004-es EU csatlakozást követően alakult meg, átvette a megszünt EU Magyarországi Delegáció feladatait, elsősorban és általában a strukturális alapok, a Kohéziós Alap hazai felügyeletének feladatait, nem csak a környezetvédelem területén.

A Magyar Államkincstár, mint a költségvetés végrehajtó szerve, mint bonyolító és egyben ellenörze̋ szervezet is részt vesz, többek között a környezetvédelmi projektek végrehajtásában is. Beszedi a különböző finanszírozási forrásokból származó összegeket (EU támogatás, önkormányzati sajáterö) majd azokat kiegészíti a hazai állami forrásokkal és ezt követően teljesiti a kifizetéseket a kivitelezök részére az igazolt, elvégzett, teljesített feladatok után.

Az Állami Számvevőszék a költségvetés végrehajtásának legföbb ellenőrző szerve a projektek végrehajtását is ellenőrizheti és ellenörzi is.

\section{A KEDVEZMÉNYEZETT ÖNKORMÁNYZATOK SZERVEZETI EGYSÉGEI}

A közösségi támogatások elnyerésének egyik alapvető feltétele legtöbbször a regionális együttmüködés, az érintett térség önkormányzatainak a támogatott cél megvalósítására irányuló közös akarata. A vizsgált projekt esetében az EU Delegáció a támogatás elnyerésének feltételeként határozta meg a Szeged és a környezỏ 32 település által létrehozott hulladékgazdálkodási konzorcium megalapítását. A támogatott fejlesztések révén létrejött közös tulajdonú közszolgáltatói vagyon hosszú távú müködtetése érdekében a konzorcium 2007. decemberében önálló jogi személyiséggel rendelkező társulássá alakult.

\subsection{A hulladékgazdálkodási konzorcium}

A szeged térségi hulladékgazdálkodási konzorciumot 33 település önkormányzata hozta létre a szegedi önkormányzat kezdeményezése alapján. A konzorcium döntéshozó szerve a 
Konzorciumi Tanács, melynek tagjai a konzorcium tagönkormányzatainak polgármesterei. A konzorcium elnöke a gesztor önkormányzat, Szeged város polgármestere.

\subsection{A gesztor önkormányzat}

A gesztor önkormányzat, a vizsgált esetben Szeged megyei jogú Város önkormányzata, feladata a konzorcium mủködési feltételeinek megteremtése, az ehhez szükséges pénzügyi és tárgyi feltételek, valamint személyi és szervezeti háttér, továbbá a szükséges infrastruktúra biztositása. Ezen a szokásos feladatkörön túl, melyet Szeged térités nélkül vállalt magára, egy sajátos finanszírozási helyzet alakult ki. Bizonyos kényszerek hatására Szeged kénytelen volt magára vállalni a projekt önkormányzati saját erejének teljes finanszírozását is. Ez a teljes programra vetitve valamivel több mint 700 millió $\mathrm{Ft}$, az eddigi bekerülési költség mintegy 13\%-a (az credeti megállapodás szerint az önrész 10\% volt).

A kedvezményezett önkormányzatok részéröl a gesztor önkormányzat polgármestere, a Konzorciumi Tanács elnöke felügyeli, jrányítja a projekt végrehajtását. Szeged esetében a polgármester bizonyos hatásköri felügyeleti ellenörzési feladatait megosztja a városüzemeltetési alpolgármesterrel, a városfejlesztési alpolgármesterrel és a gazdasági alpolgármesterrel, ez utóbbi felel a projekt szabályszerü és korrekt finanszírozásáért is.

Hasonló munkamegosztás jellemzi a polgármesteri hivatal érintetí szervezeti egységeit is. A Városüzemeltetési Iroda és a Fejlesztési Iroda elsősorban a projekt műszaki tartalmát és szakszerü megvalósítását felügyeli, ellenőrzi, míg a Közgazdasági Iroda a folyamatos finanszírozás szabályszerü bonyolításáért felel.

2001-ben ISPA Iroda elnevezéssel létrehoztak egy önálló önkormányzati szervezeti egységet a polgármesteri hivatal szervezetén belül, melynek feladata volt a szegedi ISPA projektek koordinálása. Bizonyos müködési zavarok miatt a polgármester 2003-ban megszüntette ezt a szervezeti egységet, feladatait kisebb részben a polgármesteri hivatal már említett irodáihoz, nagyobb részben a projekt bonyolításával megbízott projekt menedzsment szervezethez telepítve, amely utóbbi jelenleg is teljes felelösséget visel a projekt koordinációjáért és szükséges önkormányzati adminisztrációs feladatok ellátásáért.

\section{A PROJEKT MENEDZSMENT SZERVEZET}

A korábban ISPA, jelenleg Kohéziós Alap projektek körében csak olyan projektek elökészítésére került sor, amelyek önkormányzatok bonyolítanak, és a gesztor önkormányzat vállajta valamilyen formában a projekt operativ irányításával kapcsolatos teher túlnyomó 
részét. Több modell is kialakult a magyarországi ISPA/KA projektek végrehajtása során, ezek közül két alaptípust szeretnék megemlíteni a legfontosabbnak ítélt jellemzőkkel.

\section{1. Önkormányzaton belüli projekt menedzsment egysẻg (PME)}

Van példa arra, hogy az önkormányzat saját szervezeti keretei között hoz létre olyan projekt menedzsment egységet, amely rendelkezik a projekt végrehajtásához szükséges projekt menedzsment ismeretekkel, kapacitásokkal, illetve az önkormányzat hierarchikus rendszerébe olyan szinten kerül beillesztésre, hogy szükség esetén módja van a legfelső döntési szint elérésére, a döntések idöben történő meghozatalának biztosítására. Ez több szempontból is figyelemreméltó: (1) nem automatikus, hogy valaki képes lesz projekt menedzsment szemlélettel hozzáállni új feladata végrehajtásához, (2) elöfordulhat, a kapcsolati rendszer bonyolultsága miatt, hogy a döntési szinthez túlságosan sok áttétellel kapcsolódók a projekt végrehajtásával kapcsolatos információkat nem tudják világosan a döntéshozók elé tárni. Ahol sikeresen fel tudják mérni, milyen szakismeretre van szükség, és mekkora kapacitásra a feladat megoldására, ott sikerrel jár ennek a megoldásnak a választása. Ott azonban, ahol elvben ezt a megoldási módszert választják, de valójában csak egy korábbi munkatársat (esetleg eddigi feladatainak meghagyása mellett), vagy egy üj munkatársat beállitanak az ISPA/KA projekt végrehajtására, ott elég rövid időn belül problémák lépnek fel az elégtelen kapacitás miatt, még akkor is, ha maga a projekt menedzser megpróbál erőn felü! teljesíteni.

\section{2. Önkormányzaton kívül létrehozott $\mathrm{PME}$}

Ott, ahol felméri az önkormányzat, hogy (1) hagyományos tevékenységének keretén belül nehezen hozható létre a projekt menedzsment személettel dolgozó PME, vagy ahol (2) létszámhiány vagy egyéb okok miatt nem hozható létre a PME házon belül, ott külső projekt menedzsment egységet hoznak létre. Ez nagyon sikeres megoldás lehet, ha a külső egység kellöképpen érdekelt a feladat színvonalas és hatékony végrehajtásában (pl. az önkormányzat 100\%-os tulajdonában álló szolgáltató cég), rendelkezik a szükséges erőforrásokkal, illetve módjában áll azokat megszerezni. Ezeknél a megoldásoknál különösen fontos: (1) a külső PME szorosan tud az önkormányzathoz kapcsolódni hatékonyan információt eljuttatni - és igy nem alakul ki információhiány, amely később esetleg bizalomhiányhoz is vezethet, és (2) a PME-nek megvan a megfelelő kapcsolati rendszere, és képes az önkormányzati hatáskörbe tartozó döntéseket időben meghozatni. 


\subsection{A modellek alkalmazásának gyakorlati tapasztalatai}

Az eddigi tapasztalatok azt mutatják, hogy mindkét út járható, mindkét megoldásra vannak sikeres példák. Ugyanakkor azt is látni kell, hogy hiába jól felépített a modell, alapos döntéselökészítés után születik meg a megoldás, ha valamely szereplō nem képes (esetleg önhibáján kívül) megfelelöen teljesíteni, akkor a projekt végrehajtása látja kárát.

A szegedi tapasztalatok azt mutatják, hogy az önkormányzaton belüli projekt szervezet a szegedi önkormányzat esetében nem mủködött megfelelöen. A belyi projektek előkészitését megfelelő szakemberekkel rendelkező önkormányzati cégek végezték. A projekt elindításáról szóló döntést követöen azonban önálló önkormányzati iroda alakult a projektek koordinálására a polgármesteri hivatal szẹrvezetén belül. Az önkormányzati munkatársak megfelelő motiváció, felkészültsẻg, szakértelem és nyelvtudás hiányában nem voltak képesek a koordináció feladatát megfelelő színvonalon eilátni. Ez jelentős müködési zavarokat okozott, számos konfliktushoz vezetett, melynek eredményeként egy év elteltével a korábban az elökészítésben részt vevő önkornányzati tulajdonú cégek kaptak felhatalmazást a projektek koordinálására, további bonyolítására.

\section{A SZEGEDI HULLADÉKGAZDÁLKODÁSI PME}

A projekt bonyolitásával, végrehajtásávai a gesztor önkormányzat a Szegedi Környezetgazdálkodási Közhasznú Társaságot (jelenleg non-profit kft.) bízta meg. Tekintettel arra, hogy ez a konzorciumi szerződésben is rögzítésre került, a megbizást a konzorcium önkormányzatai is jóváhagyták. Ez sajátos helyzetet teremtett, hiszen ez egy önkormányzaton kívüli szervezeti egység, de tekintettel arra, hogy az egyszemélyes társaság tulajdonosa Szeged önkormányzata, a kötödés sokkal szorosabb, mint egy szokásos megbízási jogviszony esetében. $\mathrm{Az}$ önkormányzat részéröl a projektmenedzseri teendökkel a társaság ügyvezető igazgatóját bízták meg, aki korlátozott hatáskörben a polgármester személyes megbízottjaként felügyeli, irányitja. koordinálja a projekt végrehajtását. A folyamatosan változó végrehajtási szabályok és a bonyolult adminisztráció Szeged esetében is szükségessé tették, az önkormányzati tulajdonú cég keretein belül a jól körülhatảrolható feladat- és hatáskörrel rendelkező projektszervezet kialakítását. A társaság Müszaki Részlege felelős a fejlesztésekért, többek között a hulladékgazdálkodási projekt végrehajtásáért is.

A projektek végrehajtása nem a kivitelezési munkákat vagy az áru/eszköz beszerzéseket jelenti, hanem azt a folyamatot, ami a támogatás odaítélését követi.

E folyamat legfontosabb állomásai: 
- a támogatási szerződések aláirása,

- a tervezési munkák még hátralévő részének befejezése,

- a közbeszerzési eljárások elökészitése,

- lebonyolítása,

- a vállalkozói szerzödések aláírása,

- a vállalkozók munkája, és annak ellenőrzése,

- a kész munkák/leszállított áruk és eszközök átvétele, amennyiben ennek van értelme, akkor próbaüzeme,

- garanciális idöszak leteltéig a figyelemmel kísérés.

A részleg szakemberei ezen túl folyamatosan végzik a szükséges adminisztrációs feladatokat, az elvégzett feladatok dokumentálását. Ez nem egyszerủ feladat, hiszen az Európai Unió által elöirt eljárásrend bonyolult, nehezen áttekinthetö és a projekt elökészítésének megkezdése óta több̉ször és jelentősen változott.

\section{A PROJEKT SZERVEZETI HÁTTERÉNEK RÉSZLETES VIZSGÁLATA}

A projektben közvetlenül résztvevő, annak előkészitését és végrehajtását érdemben befolyásoló szervezeti egységeket vizsgáltam meg a szakmai felkészültség, személyi feltételek és alkalmasság, a nyelvismeret, az EU eljárásrend ismerete és a szervezeti kultúra szempontjából. (A döntéshozó szervek, igy az EU brüsszeli szervezeti egységei, a Magyar Kormány és minisztériumai, továbbá a kedvezményezett önkormányzatok konzorciuma nem tartoznak ebbe a körbe. Fontos szerepet játszott viszont a EU Magyarországi delegácićja, a KvVM Nemzetközi Támogatások Önálló Osztálya, később Fejlesztési lgazgatósága, a gesztor önkormányzat és az általa megbízott PME.)

\subsection{Az EU Magyarországi Delegációjának müködése}

Hazánk uniós csatlakozása előtt a folyamatok meghatározó szereplöje volt az EU Magyarországi Delegációja. Viszonylag rövid idő alatt kialakult egy markáns szembenállás a delegáció és a „magyar oldal” között, vélhetöen azért, mert - különösen a kezdeti időszakban - az érdekek és szempontok markánsan különböztek. A magyar kormányszervek és a kedvezményezettek is egyértelmúen abban voltak érdekeltek, hogy minél több uniós támogatást minél rövidebb idő alatt megszerezzünk, míg a delegáció szempontjai egészen más jellegüek voltak. A megkérdezett szakemberek többsége feltételezi, hogy a delegáció 
mûködẻse során politikai indíttatású taktikai elemek játszottak szerepet. A projektek elörehaladására a 2000-2003 közötti időszakban a delegáció meghatározó befolyást gyakorolt.

A kōzbeszerzési eljárás előkészítése során, a tender dokumentációk esetében olyan bonyolult és nehézkes jóváhagyási mechanizmust alakítottak ki (mindig az EU szigorú szabályaira hivatkozva), amelynek eredményeként a 2000-ben jóváhagyott projektek első tendereinek meghirdetésére csak 2003-ban kerülhetett sor. A csúszásért mindig a magyar félre háritották a felelöséget, annak szakmai felkészületlenségét okolva. Mindenesetre jól látható, hogy az unió bővitéséröl szóló sikeres irországi népszavazást követően jelentősen felgyorsultak a folyamatok, a magyar csatlakozásról szóló hazai népszavazás után pedig szinte hisztérikusan sürgették a projektek azonnali inditását. Az említett feltételezések szerint a delegáció a bỏvítésröl szóló politikai döntéseket megelözően tudatosan fékezte a folyamatokat, a végleges döntés megszületése után pedig maga is kényelmetlen helyzetbe került, mert néhány hónap atatt kellett befejezni azt, amire egyébként már három évet elpazaroltunk. A kialakult helyzetet természetesen a magyar fél fogadóképtelenségével, hozzá nem értésével, szakmai felkészületlenségével magyarázták.

A szervezet megadott szempontok szerinti vizsgálata érdekes megállapításokra ad lehetőséget. Mint utóbb kiderült az uniós „szakemberek” tényleges szakmai felkészültsége rendkívül gyenge és felületes. A projektek müszaki tartalmát illetöen érdemi segítséget nem tudtak nyújtani. Természetesen az EU eljárási szabályokat lényegesen magasabb szinten ismerték, mint a magyar oldal szakemberci, de az is kiderült, hogy ezek az ismereteik is felületesek. A vitatott esetekben a szabályértelmezések során az elsődleges szempont mindig a saját személyes felelösségvállalás elkerülése volt és nem a közös célok mielöbbi elömozdítása. Azt meg kell jegyeznünk, hogy az eljárási szabályok a vizsgált időszakban sokszor és jelentősen változtak, amiről a végrehajtók soha nem tehetnek.

A személyi feltételek és az egyes személyek szakmai felkészültsége területén is komoly problémák merültek fel. Fiatal, tapasztalatlan, olasz és spanyol nyelvterületröl származó szakemberek vettek részt az EU részéről a projektek közvetlen szakmai irányításában. Egy részük talán büntetésként élhette meg a magyarországi kiküldetést, más részük az uniós karrier egyfajta ugródeszkájának tekintette, mindenesetre jól érzékelhető volt, hogy a hazai környezetvédelem helyzetének alakulása kevésbé érdekli öket, mint a személyes elömenetel és karrier. Ezért semmilyen kockázatot nem vállaltak, kerültek minden olyan szituációt, ami akár a legkisebb személyes felelösségvállalást tette volna szükségessé. Számtalan egyeztetésre kerullt sor, ezekről bizonyára elkészültek az unió felé a semmitmondó jelentések, de a résztvevők számára sem jegyzőkönyvek, sem emlékeztetők nem készültek soha. Utólag 
több esetben fordult elő, hogy az illetékes EU szakember egyszerüen letagadta, hogy a vitatott instrukció töle származott. Viselkedésüket gyakran nagyképüség, hatalmi arrogancia, a magyar partnerek lenézése és alábecsülése jellemezte, mellyel feltehetỏen személyes és szakmai hiányosságaikat kívánták leplezni.

A nyelvismert szempontjából vizsgálva a helyzetet megállapítható, hogy a közepesnél jobb angol nyelvtudással rendelkeztek, de szerencsés lett volna néhány olyan szakember alkalmazása is, akik legalább alapfokú magyar nyelvismerettel bírnak. Alkalmaztak ugyan néhány magyar szakértőt, ezek azonban teljesen alárendelt szerepet játszottak és érdemben soha nem vettek részt az, egyeztetéseken.

A delegáció hagyományos értelemben vett önálló szervezeti kultúrájáról nem beszélhetünk, hiszen Európa különbözö országaiból véletlenszerüen verbuválódott, viszonylag rövid ideig müködő, hagyományok nélküli szervezeti egységröl van szó. Mint az EU egyik szervezeti egysége, leginkább a Mintzberg szervezeti modellje szerinti - az EU adminisztrációra oly jellemző, sokat bírált - ,gépi bürokrácia" jellemezte ezt a szervezetet. A felülröl érkezö instrukciók, utasitások, az érvényes szabályok maradéktalan, gépies végrehajtása, merev betartása, a rugalmatlan szabályértelmezések jellemezték a szervezet müködését. [Mintzberg 1979]

A delegáció munkatársai a korábban emlitett motivációs torzujások, a személyes karrier, valamint a kellő tapasztalat, szakértelem és felkészültség hiányában nem voltak képesek a koordináció felađatát megfelelő színvonalon ellátni, és a folyamatokhoz:a tölük elvárt és szükséges hozzáadott értéket biztositani. Ez jelentős müködési zavarokat okozott, számos konfliktushoz vezetett.

Összegezve leszögezhetjük, hogy a delegáció egy, az EU és a magyar fogadó szervezetek közé beékelődött jelentős hatáskörökkel és hatalommal felruházott, felesleges adminisztratív akadály volt, amely ahelyett, hogy hatékonyan segitette volna a támogatások mielőbbi lehívását, saját szerepét és feladatát a „szigorú EU szabályok és eljárásrend" maradéktalan betartásában találta meg. Mindenesetre sikerült megmutatni számunkra az „euro-bürokrácia” igazi arcát. Hazánk csatlakozásával a delegáció megszünt, feladatait a NFÜ és a KvVM Fejlesztési Igazgatósága vette át.

\subsection{A KvVM koordináló szervezeti egységei}

A KvVM Nemzetközi Támogatások Önálló Osztálya kis létszámmal, de jól felkészült, nagy szakmai tudással, megfelelö nyelvtudással rendelkező szakemberekkel kezdte meg 1999-ben az első ISPA projektek előkészítését. A csatlakozás tervezett dátumának 
közeledtével világossá vált, hogy a támogatási lehetőségek jelentős növekedése miatt ez a szervezet nem lesz elegendő a megnövekedett feladatok ellátásához. Ezért került sor az osztály átalakítására, kibővítésére, melynek eredményeként létrejött a KvVM Fejlesztési Igazgatósága, mint önálló intézmény. A bỏvités valamelyest gyengítette az ủj szervezeti egység szakmai színvonalát, hiszen számos, kevesebb tapasztalattal rendelkezö fiatal szakember került be. Mivel a régi szakemberek különbözö vezetői beosztásokba kerültek, így a közvetlen szakmai irányítảs valamelyest kompenzálta az említett hiányosságokat. Nagy nehézséget jelent a fiatal szakemberek folyamatos cserélödése, mivel a jól képzett, jó nyelvtudással rendelkező szakétrők elhelyezkedési lehetőségei a fövárosban és az unió más országaiban is nagyon jók, sokan rövid idő után (néhány hónap, 1-2 év) elhagyja az Igazgatóságot jobb személyes karrier, magasabb jövedelem reményében.

A szakemberek, projektmenedzserek nyelvtudása megfelelő, bár ennek jelentősége a csatlakozást követöen jelentősen csöklient, hiszen a hivatalos kommunikáció nyeive a magyar lett. Természetesen ma már kiválóan ismerik az EU szabályokat és az alkalmazott eljárásrendeket, ezeket képesek rugalmasan, racionálisan értelmezve a közös célok megvalósítása érdekében alkalmazni.

A szervezeti kultúra jelentősen változott az elmúlt 10 évben. A korábban a hazai minisztériumokat jellemző bürokratikus szervezeti struktúra jelentősen átalakult. Már a Nemzetközi Támogatások Önálló Osztályt sem igazán ez jellemezte, a Fejlesztési Igazgatóság müködésére már egyértelmüen az új kihivásokhoz és feladatokhoz rugalmasan alkalmazkodó, Mintzberg féle ,adhoktratikus" müködés jellemző. [Mintzberg 1979]

\subsection{A gesztor önkormányzat múködése}

A projekt megvalósítása szempontjából a gesztor önkormányzat polgármesteri hivatala, ha kisebb mértékben is, de befolyást gyakorol. Ez a csekélyebb befolyás az oka annak, hogy a szervezet müködési hiányosságai érdemben nem befolyásolták a projekt megvalósítását. Az önkormányzati munka presztízse viszonylag alacsony, az elérhető jövedelem a versenyszférához képest kevés. Ezért az önkormányzat szakemberinek felkészültsége, szakmai összetétele gyenge, a nyelvtudás minimális, az EU szabályok és eljárásrend ismerete csekély. A szervezetre háruló feladatok nagy részét a PME végzi, vagy az illetékes irodák (Városüzemeltetési, Fejlesztési, Közgazdasági) PME közvetlen irányitása és útmutatásai szerint járnak el.

A korábban ISPA Iroda néven létrehozott önálló szervezeti egység sem váltotta be a hozzáfüzött reményeket. Rövid fennállás után, meg kellett szüntetni. Súlyos és ismétlỏdő 
müködési zavarok jelentkeztek az információ áramlás során, fontos levelek, iratok, dokumentumok kallódtak el, állandósultak a hatásköri és kompetencia vitákból eredő személyes konfliktusok. A felelösséget a hibákért viszont az érintettek közül senki sem kivánta magára vállalni. Az iroda közvetlenül a polgármester alá rendelve látta el feladatait, igazán nem tudott integrálódni a polgármesteri hivatal hagyományosan bürokratikus szervezetébe. Menet közben világossá vált, hogy rendszeridegen, csak egy felesleges adminisztratív lépcső, amely a támogatók szervezeti egységei és a projekt végrehajtásáért felelös projekt menedzsment szervezet közé ékelődik: (Mintzberg szervezeti modelljét alapul véve leginkább az önkormányzatokra jellemző gépi bürokrácia és a projektek menedzselésćhez szükséges adhokratikus jelleg közötti ellentmondás okozta a problémákat.)

\subsection{A projekt menedzsment szervezet}

A Szegedi Környezetgazdálkodási Non-profit Kft. (korábban közhasznú társaság) 100\%-os önkormányzati tulajdonú egyszemélyes vállalkozás, kiemelten közhasznú szervezet, feladata a városi közterületek fenntartása és a hulladékszállítási helyi közszolgáltatás biztosítása. Mindkét terület az önkormányzati törvény által elöirt kötelezö önkormányzati feladat.

A társaság készítette elő 1999-től a térségi hulladékgazdálkodási projekt tervezetét, a 2000res sikeres elbírálást követően végezte a közbeszerzési eljárás előkészitését és lebonyolitását. Hivatalos felhatalmazást és megbízást 2000-ben kapott a szegedi önkormányzattól, melyet később a konzorciumi szerzčdés aláirásával a csatlakozó 32 település önkormányzata is megerösített. Mint nem önkormányzati PME az önkormányzat megfelelő szervezeti egységeivel szorosan együttmüködve végzi a projekt végrehajtásával kapcsolatos feladatokat.

A társaság a rendszerváltozást követő időszakban jelentősen átalakult, ez tette lehetővé, hogy alkalmassá vált a projekt menedzsment szervezeti egység funkcióinak ellátására. Jogelödje a Szegedi Városgazdálkodási Vállalat 1992. október 1-jén került Szeged Megyei Jogú Város Önkormányzatának tulajdonába. Ezt követően a vállalat életében alapvetỏ és mélyreható változások történtek. Elsö lépésként a távhőszolgáltató ágazat leválása történt meg, melynek eredményeként létrejött az önálló SZETÁV, a Szegedi Távhőszolgáltató Vállalat. A társasági törvény elöírásai alapján a korábbi állami és önkormányzati vállalatokat gazdasági társasággá kelletı alakítani, a szegedi VGV esetében erre 1994-ben került sor, ekkor alakult meg a Szegedi Környezetgazdálkodási Kft. Az önkormányzat közgyülése egy évvel később úgy döntött, hogy a korlátolt felelösségü társaságot közhasznú társasággá alakítja. A társaság tulajdonosa 2002-ben az alaptevékenységekei, a közterület-fenntartási és a hulladékgazdálkodási szolgáltatásokat két külön gazdasági társasággá szétválasztotta. $\Lambda$ két 
sikertelen privatizációt követően a szétválasztott két gazdasági társaságot, a Közterületfenntartási Kht.-t és a Hulladékgazdálkodási Kht.-t Környezetgazdálkodási Kht. néven újraegyesítették. A kht. megnevezés az idei évben törvényi változások miatt non-profit kft.-re változott.

Az elmúlt 15 év kihívásai, a politikai és gazdasági környezet gyökeres megváltozása a társaság teljes átalakitására kényszerítette a cẻg vezetését. A korábbi lineáris szervezeti felépítést divizionális, valamint egyes tevékenységek esetében mátrix jellegü szervezet kialakításával váltották fel. $\Lambda$ közterület-fenntartási tevékenységek, a hulladékgazdálkodási szolgáltatások, valamint a közgazdasági (pénzügyi, számviteli és adminisztrációs) tevékenységek három önálló divízió keretében müködnek. A szállítási-logosztikai szolgáltatások, a fünyírás mint kiemelt tevékenység, a karbantartás és javítás (TMK) formálisan a Hulladékgazdálkodási divizió szervezetén belül, de valójában mártix rendszerben müködik. Jelentősen megváltozott a felsö és középvezetöi kar szakmai összetétele, önálló munkavégzésre képes, többségében diplomás fiatal szakemberek kerültek a vezetői posztokra. A szervezet képes a gyors változásokhoz is rugalmasan alkalmazkodni és az ủj kihívásoknak is megfelelni.

A szervezetfejlesztés egyik fontos kiegészitōje volt a stabil értékrendet tükrözơ vállalati kultúra megteremtése. Meghonosították és támogatják a muikavállalók érdekeit is szem elōtt tartó, következetes de humánus vezetői magatartást, melynek célja a vállalathoz tartozás érzésének erösítése, a szakmai öntudat kialakítása. A közszolgáltatási szemlélet erősítése érdekében, minden évben év végi jutalom kifizetésére kerül sor, ugyan úgy, mint a közalkalmazottak 13. havi fizetése. A vállalthoz tartozás erösítését célozza a törzsgárda jutalom is, melynek átadására minden évben ünnepélyes keretek között történik.

A hulladékgazdálkodási projekt végrehajtását az ügyvezető irányításával (aki a polgármester által kinevezett önkormányzati projekt menedzser) a társaság Mũszaki Részlege biztosítja. Más feladataik mellet folyamatosan 5 fö áll rendelkezésre szükség szerint a felinerülő fèladatok ellátására. A szervezet gyenge pontja a nyelvtudás, egyedül az ügyvezető rendelkezik biztos angol nyelvtudással. (A csatlakozás óta ez már nem jelent komoly hátrányt.) Az EU szabályok és eljárásrend ismerete ma már nem okoz gondot, a társaság szakemberei folyamatosan figyelemmel kísérik a változásokat és időben megteszik a szükséges intézkedéseket. Korábban, elsỏsorban 1999 és 2003 között jelentett ez igazán problémát, amikor az EU Delegációval vivott csatákban hasznos lett volna az uniós szabályok és eljárásrend mélyebb ismerete. 


\section{ÖSSZEFOGLALÅS}

$\mathrm{Az}$ Európai Unió támogatásával megvalósuló magyarországi projektekben számos nemzetközi, nemzeti, regionális és helyi szintü szereplö, szervezet vesz részt, melyek szervezeti struktúrája és kultúrája egyrészt nem minden esetben ideális a projektmenedzsment szempontjából, másrészt az egymással együttmüködni kénytelen szervezetek közötti jelentős eltérések is nehezitik a hatékony kooperációt. Dolgozatomban ezt a problémakört mutatom be a Szegedi Regionális Hulladékgazdálkodási ISPA Projekt tapasztalatai alapján.

Az európai uniós csatlakozás komoly lehetőséget jelentett az új tagországok számára, különösen a környezetvédelmi infrastruktúra fejlesztési projektek közösségi támogatása következtében. Ezek a támogatások viszonylag rövid idő alatt biztosíthatják a közèp-kelet európai országok számára a felzárkózást a világ fejlettebb országainak színvonalahoz. Világosan kell azonban látni, hogy a támogatási rendszerek bonyolultak és a megszabott. feltételek rendkivüi szigorúak. Egyrészt szükség van a hatékony nemzeti szintü szabályozás és bonyolítás rendszerénck és hatékony szervezeti hátterének kialakitására, másrészt a kedvezményezettek jelenleginél lényegesen nagyobb szakmai felkészültségének biztosításära.

\section{FELHASZNÁLT IRODALOM}

1. Görög M. (2001): Általános projektmenedzsment, Aula Kiadó, Budapest *

2. Dobák M. (1998): Szervezeti formák és vezetés, KJK, Budapest

3. Mintzberg, H. (1979): The Structuring of Organizations, Prentice Hall, New Jersey

4. Görög M.(2001): Bevezetés a projektmenedzsmentbe, Alila Kiadó, Budapest

\section{Felhasznált dokumentumok}

„Szeged Regionális Hulladékgazdálkodási Programja" ISPA projekt konzorciumi szerződése „Szeged Regionális Hulladékgazdálkodási Programja” ISPA projekt dokumentáció „Szeged Regionális Hulladékgazdálkodási Programja” ISPA projekt finanszírozási szerződése (Financing Memorandum) és támogatási szerződése „Szeged Regionális Hulladékgazdálkodási Programja” ISPA projekt tender dokumentációk 